\title{
Conflict Resolution and Punishment in Hungarian Medieval Laws and in Practice
}

Modern scholarship realizes that statutory law of Árpádian Hungary may not have meant to regulate actual situations, but only to follow general medieval patterns of Christian rulers issuing codes of law. Sources on actual legal practice show a different picture of the practice of conflict resolution and of punishment in comparison with the laws. They report a higher number of extrajudicial settlements and lack of any corporal punishment, in harmony with the results of research of scholars from Western Europe. This may have been caused by the fact that the immediate superior authority of the researched communities was the king whose court was far away, and the freemen (later nobles) had to settle their disputes by themselves. In such a situation corporal punishment was not the solution. Instead, compository payment was imposed in order to re-establish peace and order.

\section{Introduction}

In previous research it was often supposed that the regulations comprised in the statutory law of Árpádian rulers actually reflect a valid legal practice of conflict resolution during the first three centuries of the existence of the Hungarian Kingdom. However, modern research realized that the first legislative attempts may not have served to regulate actual situations, but were rather meant to follow the general medieval patterns of "what a Christian ruler should do" namely to issue a code of law. Extant charters as sources on actual legal practice namely show a different picture of the practice of conflict resolution and punishment in comparison with the laws of the first rulers of Hungary. They report a higher number of extrajudicial settlements and lack of any corporal punishment, which is in harmony with the outcomes of research of scholars from the Western Europe. ${ }^{1}$

\footnotetext{
${ }^{1}$ The paper was written within the project "Cultural and religious differences, migration and human
}

\section{Sources}

The paper is using several types of primary sources. They are mainly (1) charters derived from the activity of trustworthy places (a type of notarial office in medieval Hungary), royal court, or offices of highest officials, (2) Register of Oradea (Várad) as a source of information on the practice of ordeals by hot iron, (3) chronicles and legends as narrative sources, and finally (4) law codes by St. Stephen, St. Ladislas and Coloman from the period of Árpádian Hungary.

As far as charters are concerned, we used the Wenzel's edition, ${ }^{2}$ Szentpétery's registry, ${ }^{3}$ Slovak edition by R. Marsina, ${ }^{4}$ and a photographic collection of charters kept with the MOL Hungarian National Archives.

rights", no. 1/0507/12, financed by the VEGA Slovak Republic.

${ }^{2}$ WenZEL, Codex diplomaticus. It contains a total of 3,858 charters, mostly of official provenance.

3 SZENTPÉTERY, Regesta I; SZENTPÉTERY, BORSA, Regesta II/2-3; SZENTPÉTERY, BORSA, Regesta II/4.

${ }^{4}$ MARsina, Codex diplomaticus. 
The Register of Oradea from the years 12081235 , used as another primary source, represents Europe-wide a valuable source of knowledge on the ordeals by hot iron. We used an older, but respected edition by J. Karácsonyi and J. Borovszky. ${ }^{5}$ Of the 389 entries, ${ }^{6}$ only 20 cases do not contain a report of any dispute.

Legends and Chronicles are another significant source of knowledge of dispute resolution practice, although mostly they contain only references to the conflicts in relation to the sovereign, therefore, describe only one type of dispute resolution - the vertical one. In this work, we used a shorter legend of King St. Stephen. ${ }^{7}$

When analyzing the Hungarian laws, we used the bilingual Latin-English edition by János M. Bak. ${ }^{8}$ For the period of Árpádian Hungary, particularly the first volume of this edition is relevant, which contains codes and decrees of the first Árpádian rulers.

Secondary literature provides an overview of foreign (mainly English and German-speaking) bibliography on this subject, which offered a comparative material to the Hungarian sources on dispute resolution practice.

\section{Judicial Dispute Resolution}

In terms of judicial system in Árpádian Hungary, at the highest level, judicial functions were performed by the King, the Palatine, and the Judge Royal. The Palatine exerted justice also in the countryside - within the so-called Palatinal congregations, usually taking place for two or more counties. Since the 13th Century, there appear special royal judges, referred to as biloti

\footnotetext{
${ }^{5}$ KARÁCSONYI, BOROVSZKY, Regestrum Varadinense.

${ }^{6}$ Out of which in 348 cases, ordeal by hot iron was used according to Bartlett's calculation. BARTLETT, Trial by Fire 63 .

${ }^{7}$ MARSINA, Legendy.

${ }^{8}$ BAK, BónIS, SWEENEY, The Laws of the Medieval Kingdom of Hungary.
}

(bilochi) regales. At the same time, the emerging noble county established its own judicial bodies - county congregations acting as judicial seat. Colonists, based on their royal privileges, were subject to their own judicial authorities, and not to the county judges.

Thus, there existed authorities, the official function of which has been the resolution of disputes. Delegation of a dispute often took form of an occasional ad hoc mandate by the ruler to resolve the specific dispute. However, often the function of the judge resulted from the high administrative or church position itself. Perhaps such ambiguity of jurisdiction caused a chaos in a case from 1299, where the parties declared that the judges in their case were false. ${ }^{9}$

The primary sources make it clear that the task of a judge was, as it is in the case of an arbitrator or mediator, only to allow for the composition between the parties, and only where necessary to express binding decision by virtue of their official capacity. The final decision did not differ much from the settlement reached by parties on their own or through an intermediary, or an arbitrator. Therefore, there could indeed be confusion and overlapping of responsibilities and terminology. Judges, just like arbitrators invoked no legal standards ${ }^{10}$ (for example, the laws of first kings) in the proceedings, and their decisions in most cases involved only granting of financial compensation in favour of one of the parties without imposing any other punishment (with rare exception of the death penalty and in the earlier period sale into slavery or shaving the head).

Generally, the court minutes and charters with judicial sentences, are extant in very low num-

\footnotetext{
9 "Zoda, Bors et Nicolaus deberent comprobare, ut magister Leurente, Comes Mathyas et magister Heym sint falsi iudices, et praedictae litterae eorum inquisitoriae similiter falsae et modo praehabito emanatae" WENZEL, Codex diplomaticus 5, 1299, Nr. 154 (MOL DF 259837).

${ }^{10}$ ECKHART, Magyar alkotmány és jogtörténet 154.
} 
bers in contrast to settlements reached through arbitration or by the parties with the help of mediators. This is surely not caused by an absolute replacement of judicial dispute resolution by settlements out of court - both forms existed side by side. ${ }^{11}$ Since there are only few extant court minutes and judicial decisions, it may well be possible that the process and decision itself was also not that important as the execution thereof, which took place with the help of court administrators and trustworthy places (a sort of notary public institution), which at the same time produced reliable documentary evidence. ${ }^{12}$ These charters are our only evidence on judicial conflict resolution.

Further in this paper we will deal only with the judicial conflict resolution, and only with the final step in the process of conflict resolution, trying to compare the system of penalties presupposed in the laws with the penalties actually applied in practice of judicial dispute resolution.

\section{Penalties in laws and in practice}

Concerning the penalties applied, Ákos Timon already in the beginning of the 20th Century tried to establish a categorization thereof:

(1) death sentences,

(2) corporal punishment, either in the form of mutilation or applied to the skin and hair,

(3) deprivation of liberty with the meaning of enslavement, imprisonment, or expulsion from the community,

(4) pecuniary penalties, either as compository payments ("die compositionalen Vermögensstraf$\left.e n^{\prime \prime}\right)$, or fines (not paid to the victim or their relatives, but rather to the judge), or as the redemption of corporal punishment ("die Straflösungs-

\footnotetext{
${ }^{11}$ BROWN, Konfliktaustragung 50.

12 ŠvECOVÁ, GÁBRIŠ, Riešenie konfliktov.
}

summen"), or finally as forfeiture of assets (total or partial). ${ }^{13}$

Another well-known Hungarian legal historian Ferenc Eckhart, in his classical work distinguished:

(1) death penalty,

(2) mutilating punishments,

(3) deprivation of liberty,

(4) pecuniary penalties and

(5) shaming punishments. ${ }^{14}$

It is clear that both authors were leaning mainly on the Árpádian lawbooks. We will try in this paper to compare these schemes to the actual everyday situation reflected in the extant primary sources.

\subsection{Death penalty}

The capital penalty was regularly connected to the loss of property. Laws of King Stephen and Ladislas imposed this penalty for a betrayal of the king and kingdom ${ }^{15}$ and for the intrigues against the counts. ${ }^{16}$ In addition to this protection of public interests, capital punishment was anticipated also in matters of private interest, such as the murder by sword ${ }^{17}$ or attempt for the offense. ${ }^{18}$ Similarly, stealing, ${ }^{19}$ buying and selling stolen property ${ }^{20}$ or attacking a person searching for lost or stolen property ${ }^{21}$ was to be punished by the death penalty.

Extant charters show that the death penalty in practice took form of hanging. Charters mention hanging only marginally in other contexts, for

\footnotetext{
${ }^{13}$ TIMON, Ungarische Verfassungs- und Rechtsgeschichte 429-440.

${ }^{14}$ ECKHART, Magyar alkotmány és jogtörténet 154.

${ }^{15}$ Stephen II: 2.

16 Stephen II: 12.

17 Stephen II: 11.

${ }^{18}$ Stephen I: 16.

${ }^{19}$ Ladislas II: 1, Ladislas II: 2, Ladislas II: 12, Ladislas II: 14, Ladislas III: 8, Ladislas III: 10.

${ }^{20}$ Ladislas II: 7.

${ }^{21}$ Ladislas II: 5, Ladislas III: 13.
} 
example, when discussing the forfeiture of assets by Royal fisc. ${ }^{22}$

Capital punishment by hanging is associated with loss of property e.g. in 1239 in case of theft. ${ }^{23}$ The terminology of shedding of blood (sanguinis effusio) is used here, despite the fact that when using hanging as a method of capital punishment, the blood is not shed at all. The term was rather a general term to describe the death penalty. This is shown also by a charter from 1262 where the judge imposed the death penalty (again, effusio sanguinis) upon the perpetrator and forfeiture of property upon the accomplices and participants in the crime. ${ }^{24}$

It is interesting in this context that in 1299 , burning of the perpetrators is mentioned, according to the "statuta Regni." 25 In the extant laws of Árpádian rulers, such a method of capital punishment is not mentioned at all.

One may conclude that the death penalty, which according to Western authors was used less

\footnotetext{
22 E.g.: "terram Gurbuse filii Miconis, existentem in Comitatu Zaladiensi ultra Dravam, que ad manus ipsius Stephani Bani fuerat devoluta, eo quod idem Gurbuse culpis suis exigentibus finivit in patibulo vitam suam, contulisset Sceme filio Pouche servienti suo pro suis servitiis" WENZEL, Codex diplomaticus 7, 1258, Nr. 341 (MOL DL 478).

23 "Pousa et Laurencius contra Rekam et Bolosey in examine duelli pro furti crimine sunt convicti, qui Pousa suspendio condempnatus, Laurencius vero fugiens ecclesiam introivit, et sic sanguinis evasit effusionem, totaque eorum possessio tam ad manus partis adversae, tam ad nostras (palatine Dionysius) fuit devoluta." Wenzel, Codex diplomaticus 7, 1239, Nr. 51 (MOL DF 252591).

24 "Ideo autem decrevimus (palatine H.), quod idem Sank, ubicunque inventus fuerit, impediatur, et ad iudicem ducatur ad sanguinis effusionem, et apud quem inventus fuerit, ille non audeat eum retinere; praenominatis autem quinque hominibus non decrevimus fieri effusionem sanguinis, sed quidquid habent, tam in possessionibus, quam in aliis totum amittant." WeNZEL, Codex diplomaticus 8, 1262, Nr. 32.

25 “iuxta statuta Regni in eorum personis igne cremandos et morte debita condempnandos eosdem sententialiter decrevimus" WENZEL, Codex diplomaticus 5, 1299, Nr. 154 (MOL DF 259837).
}

frequently than fine, ${ }^{26}$ occurs in our sources quite often. The penalty was applied only within the judicial settlement of disputes - as opposed to settling the disputes out of court. This difference arises from the fact that the arbitrators or the parties themselves did not have the competence to decide about life and death, and also from the fact that the death penalty cases were mostly cases of public offenses such as treason against the sovereign or notorious criminal activity, and the disruption of public order. Such cases were usually not addressed by arbitrators and mediators at all.

\subsection{Corporal punishment}

Corporal punishment in the laws of the first kings and the subsequent legislation up to the year 1301 can be divided into penalties on the skin and hair (or classifiable within a particular category of shaming penalties) and mutilating penalties.

The first category includes e.g. cutting the hair and beating those who remained at home on Sunday instead of participating in the mass, ${ }^{27}$ whipping and cutting the hair of an adulteress, ${ }^{28}$ flagellation of witches, ${ }^{29}$ shaving, tying and flagellating a person who interfered with the protection of home, ${ }^{30}$ shaving half of the head of a fled slave $^{31}$ etc.

Doubts may arise in connection with a shaven head. Cutting the hair sometimes seems to be a sign of ecclesiastical serfs and not a punishment. ${ }^{32}$ For example, the charter of 1092 from the period of reign of King Ladislas, indicates that some families have tried to change their status

\footnotetext{
${ }^{26}$ Dean, Crime in Medieval Europe 130.

27 Stephen I: 9.

${ }^{28}$ Stephen I: 28.

${ }^{29}$ Stephen I: 34.

${ }^{30}$ Ladislas II: 11.

${ }^{31}$ Coloman 41.

${ }^{32}$ More on ecclesiastical serfs (Hung. torlók or dusnokok) cf. HUNYADI, Signs of Conversion 112.
} 
to "dvorník/udvarnok" (somewhat privileged direct royal subjects), ${ }^{33}$ but the judge decided to return the families to their original ecclesiastical landlord and cut their hair. ${ }^{34}$ It is unclear whether this was a punishment or the expression of their dependent status.

The charters also describe a practice, which is not mentioned in the laws at all. It was a form of public penance, walking barefoot with a number of retinue with bare swords. ${ }^{35}$ Its origin seems to be rooted in the Church penance.

The second category of corporal punishment (i.e. mutilating) was a talionic ("eye for an eye") mutilation of the body of the offender, ${ }^{36}$ loss of tongue for intrigues, ${ }^{37}$ cutting off the nose of bondmen $^{38}$ or of a married woman ${ }^{39}$ for theft, and many others. Strikingly, such penalties have not been found in the charters reporting the actual practice. Only one charter mentions the possibility of a talionic mutilation of hands of the offender, who injured the hand of a victim, but here it seems to have been only a way of exerting pressure on the offender to force him to pay financial compensation, ${ }^{40}$ and the conflict was finally settled by the payment of an amount agreed upon by the "discrete men."

\footnotetext{
33 "quidam diabolico instintu voluerunt praedictas familias a servitio supradictae ecclesiae subtrahere, et in ministerio udvornicorum subiugare." WENZEL, Codex diplomaticus 1, 1092, Nr. 9.

34 "servorum Regis [...] capita tonsa sunt iussu Sar Comitis." Ebd.

35 "item idem E. cum duodecim hominibus consimilibus sui, nudis pedibus, gladiisque evaginatis in manibus eorum positis, debet supplicare praetaxato M. Magistro et excessus suos luere" Wenzel, Codex diplomaticus 2, 1239, Nr. 58.

${ }^{36}$ Stephen II: 3.

37 Stephen II: 14.

${ }^{38}$ Ladislas II: 2, Ladislas II: 10.

${ }^{39}$ Ladislas III: 6.

40 "in ultionem unius dextere praefatorum virorum quatuor manus truncarentur." WENZEL, Codex diplomaticus 6, 1227, Nr. 284 (MOL DL 104878).
}

In general, mutilation of the body of the offender is mentioned only in chronicles, in connection with rebellion against a legitimate ruler. That is the case of blinding of Vazul, Álmos and Béla ${ }^{41}$ in Hungary. Challenging the authority of the ruler is in fact very often punished by blinding. According to G. Bührer-Thierry there is a shift from blinding as punishment of martyrs in the late antiquity to the sanction used against rebellious members of the royal family and others who have committed treason, in order to make them unfit to rule. ${ }^{42}$

As in the case of the death penalty, it seems that corporal punishment was imposed only by judges, not arbitrators or mediators. In most cases, however, the courts imposed only embarrassing penalties. Mutilating corporal punishment began to appear increasingly in practice only from the $14^{\text {th }}$ and $15^{\text {th }}$ centuries onwards, when all Europe was inspired by the sanctions present in the revived Roman law, and described in hagiographic legends. ${ }^{43}$

\subsection{Pecuniary penalties}

Pecuniary penalties anticipated in the laws can be divided into those redeeming corporal punishment (offender could choose between paying the financial penalty or suffering corporal punishment), the penalty of loss of property (partial or complete), and compositional payment. The first category, the category of redeeming sanctions includes redeeming the forfeiture into slavery in case of fornication committed with a female slave, ${ }^{44}$ or theft committed by a married woman - she was to be redeemed by her husband. ${ }^{45}$

\footnotetext{
${ }^{41}$ Vazul was a cousin of Stephen I., Álmos was a younger Brother of king Coloman, and Belo (later King Belo II. the Blind) was the son of Álmos.

42 BÜHRER-THIERRY, Just Anger.

${ }^{43}$ KLABOUCH, Staré české soudnictví 263.

${ }^{44}$ Stephen I: 28.

45 Stephen I: 31.
} 
Another type of pecuniary penalty is forfeiture of property. According to Stephen I: 8, the one who worked on the Lord's day, should lose the oxen he used. The sale of a horse in the border areas, in turn, was to be punished by confiscation of the horse. ${ }^{46}$ The lie on the title of possession, namely in case of claiming that the title of ownership was a deed of gift, the liar was to lose the thing. ${ }^{47}$ In a later article 1298:15, forfeiture of landed property was imposed for illegal minting of coins.

From among the examples from practice, one may mention a case of loss of property for infidelity against the King from 1287.48

Another form of pecuniary sanction is a fine. However, it is sometimes difficult to distinguish between compositional payment (paid to the victim) and fine (payable to the judge). More or less convincing is an example of fine in the laws of the King Stephen I. for enslaving a free man. The perpetrator had to pay 50 (or 12, depending on social status) young oxen and the fine was to be divided between the king and counts. ${ }^{49}$ In practice, however, examples of penalties payable to the king or counts are rare to find.

A combination of fine and compository payment was common in the laws. A typical example in the laws of King Stephen ${ }^{50}$ is a case of kidnapping a girl. The girl was to be returned to her parents, and the offender had to pay five or ten young oxen. Similarly, in case of the arson, offender had to rebuild the house and pay 16 young oxen, worth 40 solidi. ${ }^{51}$

\footnotetext{
${ }^{46}$ Ladislas II: 6.

47 Stephen II: 11.

48 "praedium filiorum Henrici Modur vocatum, situm in Comitatu Posoniensi, cum suis pertinentiis, attinenciis et utilitatibus universis, propter infidelitates suas manifestas ab ipsis filiis Henrici auferendo" WenzeL, Codex diplomaticus 12, 1287, Nr. 378 (from 25. 1. 1287).

${ }^{49}$ Stephen I: 22.

${ }^{50}$ Stephen I: 27.

${ }^{51}$ Stephen I: 32.
}

The charters examined and the Register show that most conflicts were resolved through compositional payment. The Register contains only four cases in which we have a sentence imposed by a judge reported, ${ }^{52}$ and from among these, in the case from 1234, a compositional payment of eight talents and ten pensae is mentioned. ${ }^{53}$

The charters offer an example of a compositional payment as a punishment for burning down the chapel of St. James and causing further damage in $1220.5^{4}$ In another case from 1226, the amount of compensation was later moderated by the intervention of the bishop. ${ }^{55}$

It can thus be concluded that the fine and compensation were indeed the most widely used type of sanction. ${ }^{56}$ At the same time, it may have also been the only way to reach a compromise in case of dispute between parties of the same social status in a society where state institutions were significantly more distant to everyday life.

\subsection{Loss of liberty}

Another penalty according to laws of Árpádian rulers was loss of liberty (freedom). The laws distinguished between two types of sentences imprisonment and slavery.

\footnotetext{
${ }^{52}$ Altogether 26 judicial decisions are mentioned, but the punishments are not reported..

53 374/1234: "secundum sententiam praedicti iudicis...condemnatus est [...] octo marcas et decem pensas, totaliter persolvit, nobis praesentibus" KARÁCSONYI, BOROVSZKY, Regestrum Varadinense.

54 "adiudicavimus secundum comparationem terrae Abbatis, de terra illorum assignari tantundem, si haberent; et si non haberent, pro illa terra et talionem et pro dampnis illatis in ipsa terra, de rebus vel de personis eorum redderentur XXX et V marcae" WenZEL, Codex diplomaticus 1, 1220, Nr. 92.

55 "habito iobagionum nostrorum consilio et assensu ad examen duelli iudicavimus exequendum. Et quia dictus Muterinus ad terminum praedictum non venit nec misit, ipsum in CC marcis tam pro privatione oculorum, tam pro dampnis que sibi, intulerat, condempnavimus" WeNZEL, Codex diplomaticus 11, 1226, Nr. 129 (SZENTPÉTERY, Regesta I, Nr. 579).

${ }^{56}$ Cf. DeAn, Crime in Medieval Europe 130.
} 
Imprisonment was applied in laws of King Stephen e.g. for non-observation of feast days and for eating meat on Fridays. ${ }^{57}$ Ladislas' laws imposed this sanction e.g. in case of theft from one's own noble relatives. ${ }^{58}$ As far as practical cases of imprisonment are concerned, the issue of prisons in the Middle Ages was not researched satisfactorily yet. ${ }^{59}$ It is mostly claimed that prison in the Middle Ages was used only as a means of detention (custody), for a sake of later punishment. A French statute from as late as 1430 states that "Carcer non fuerit introductus ad poenam, sed ad custodiam." 60 Trevor Dean, however, pointed out that the monasteries had their own prisons already since the earliest times and in the $12^{\text {th }}$ century, bishops had their own prisons. ${ }^{61}$

The Hungarian legal history seems to have understood prison just as "custodia", in which the offender was awaiting the actual penalty. Although the prison (carcer) was mentioned already in the laws of the first kings, and also in laws of Andrew III., ${ }^{62}$ there are only few references to the actual existence of prison. Regestrum Varadinense mentions prison (carcer) and its guards in the 13th Century, ${ }^{63}$ however, based on this brief mention, one can not identify the real nature and purpose of the carcer - namely whether it was a prison or a detention. In another case, ${ }^{64}$ Regestrum mentions that two iobagiones were to be kept in carcer for as long as it would seem appropriate to the count. It would therefore rather seem to be a punishment. One may also

\footnotetext{
${ }^{57}$ Stephen I: 10; Stephen I: 11.

${ }^{58}$ Ladislas II: 9 .

${ }^{59}$ Cf. Geltner, Medieval Prisons.

${ }^{60}$ CARRIER, Une Justice pour rétablir la concorde 241.

${ }^{61}$ DEAN, Crime in Medieval Europe 121.

${ }^{62}$ Mezey, Kerker 389-391.

${ }^{63}$ Case Nr. 223/1219. KARÁCSONYI, BOROVSZKY, Regestrum Varadinense.

${ }^{64}$ Ebd., case Nr.341/1222: "Nominati autem duo iobagiones carcerem intrare teneretur ibi, quoadusque vellet comes, moraturi."
}

draw attention to the punishment of pagan priestesses Rasdi, which is mentioned in the Chronici Hungarici Compositio saeculi XIV. During the pagan uprising in Hungary in 1046, the pagan priestess Rasdi should have been kept in prison for so long that she has eaten her own feet out of hunger before she died. ${ }^{65}$ Even in this case, however, it is not clear whether prison was the punishment, or merely a custody in which Rasdi was waiting for an actual penalty.

The second type of loss of liberty, enslavement, occurred in the law much more frequently than prison: a free man fornicating with a bondswoman, could be sold into slavery, just like in case of fornicating bondspeople. ${ }^{66}$ Special situation was the enslavement connected to forfeiture of all property - according to the laws of Ladislas, if a thief escaped from the hands of the person who took over the guarantee for him, both were to be sold by the judge into slavery and their property was forfeited to the royal fisc. ${ }^{67}$

It is to be noted though, that although sources indeed speak of the slaves in Hungary up to the 13th century, we do not have enough information on the nature of the slavery. ${ }^{68}$

An example on the practice of enslavement is to be found e.g. in the Register, where an offender was forfeited into slavery along with his wife and children as a punishment for a false accusation of theft in $1235 .{ }^{69}$ In charters, on the other hand, the loss of freedom in either form - imprisonment or enslavement - is mentioned only very rarely.

\footnotetext{
65 "Rasdi capta fuit et tamdiu in carcere fuit reclusa donec recomederet pedes proprios, ibidem quoque moreretur" Chronici Hungarici Compositio saeculi XIV, 338. ${ }^{66}$ Both in Stephen I: 28.

${ }^{67}$ Ladislas II: 1.

${ }^{68}$ Cf. BollA, A jogilag egységes jobbágyosztály kialakulása.

${ }^{69}$ 388/1235. KARÁCSONYI, BOROVSZKY, Regestrum Varadinense.
} 
A particular type of loss of liberty, respectively a confirmation of lost liberty is perhaps the already mentioned case of shaven head, symbolizing the dependent status.

\subsection{Deprivation of office, deprivation of privileges and of noble status}

Deprivation of office was imposed in the laws of the first kings as punishment for a count, who would allow selling and buying horses at the borders of the kingdom,,$^{70}$ or should he violate a royal decree..$^{71}$ In the $13^{\text {th }}$ century it was an anticipated punishment for a Palatine, who would mismanage the affairs of the king and kingdom. ${ }^{72}$ Judge, in turn, should have lost his office should he arrest a nobleman. ${ }^{73}$

In practice, in charters, we found one isolated case, when the count Lawrence was indeed removed from office for his offenses. ${ }^{74}$

Concerning a similar sanction of deprivation of privilege, this was also a very rare punishment, mentioned only in the article 1298:15. The loss of the privilege to hold a market was to be imposed for restricting the free circulation of silver currency.

Similarly, the loss of noble status was regulated in the Árpádian laws only once. It was in the same decree, art. 1298:1, for a failure to return the occupied property. However, it is important to note, that in the past the nobility was only shaped and there were no clear rules as to the acquisition or loss of nobility. We found no example of such a judicial sanction neither in the charters, nor in the Register.

\footnotetext{
${ }^{70}$ Ladislas II: 17.

${ }^{71}$ Ladislas III: 15.

72 Art. 1231:1.

73 Art. 1298:13.

74 "Laurentium filium Ompud Comitem in Gerha primo statuissemus, non ut probus in eo aliquid lucri fecit, se tanquam malus mala intulit, de quo Comitatum hunc denuo abstulimus, penam, ut meruit inferentes" WENZEL, Codex diplomaticus, 1, 1228, Nr. 151.
}

A loss in a dispute by contumacy, e.g. for leaving the palace before the judgment was promulgated, or due to a failure to appear before a judge, should not be considered a specific penalty, but rather a procedural effect.

On the other hand, the Register contains many situations where a party did not appear before a judge or a Chapter in order to undertake an ordeal and was therefore convicted. Overall, in the Register there are 37 such cases and in 14 cases from among them, the judge expressly declared the party for convicted. In these cases, unfortunately the Register contains no record of any punishment.

\subsection{Ecclesiastical penalties}

Excommunication and other ecclesiastical penalties (fasting, penance, interdict) represent a specific type of punishment. In general, the penance had both sacral as well as disciplinary aspects, renovating the grace of God towards the sinner. ${ }^{75}$ Árpádian laws imposed penance either as a separate punishment or in conjunction with another penalty. Thereby, the connection of penance with a secular punishment clearly indicates the understanding of an offense as a sin. ${ }^{76}$ The excommunication is to be found in the Árpádian laws mostly from the $13^{\text {th }}$ century onwards, although it has been known already in the $11^{\text {th }}$ century Art. 74 of the Synod of Esztergom for a conspiracy against the king. It was to be imposed for not returning the occupied property, ${ }^{77}$ for failure to notify robbery, ${ }^{78}$ for providing alms to excommunicated monks or for the

\footnotetext{
${ }^{75}$ McNeILl, Gamer, Medieval Handbook of Penance. 15. More on penance, cf.: HAMILTON, The Practice of Penance. On public penance: MANSFIELD, The Humiliation of Sinners.

${ }^{76}$ On the use of new religion in order to prevent blood feud, cf. BAK, Signs of Conversion 118.

77 Art. 1298:1.

78 Art. 1298:3.
} 
protection given to these monks, ${ }^{79}$ and others. Excommunication should have also been a punishment for the king, if not respecting the rights of nobility as specified in the Golden Bull from 1222, and in the confirmations of Golden Bull from 1231 and 1298 (article 1298:16).

Fasting was imposed under the Árpádian laws for killing, ${ }^{80}$ especially killing one's own wife, ${ }^{81}$ for the consumption of meat on Fridays and during Feast days, ${ }^{82}$ for violation of an oath, ${ }^{83}$ and also in the witch trials. ${ }^{84}$

In charters that we analyzed, from among the ecclesiastical sanctions, the excommunication was used the most - either by the Pope himself, his legate, or by the Archbishop of Esztergom. The Pope punished the Bishop of Csanád by excommunication for imprisonment of the abbot and monks of the monastery of Bistra. ${ }^{85}$ The Papal legate Jacob from Praeneste excommunicated knight Fabian because of his contumacy in a dispute. ${ }^{86}$ However, Fabian as a member of the family of Hont-Poznan, whose brothers were high officials in the court of Andrew II., apparently did not worry much about the excommunication. ${ }^{87}$

In another case, the Archbishop of Esztergom, Vladimir, excommunicated Magister John, governor (banus) Nicholas and count Henry ${ }^{88}$ for damage caused to the Zagreb chapter by violations of its ecclesiastical freedoms, namely by

\footnotetext{
${ }^{79}$ Art. 1298:4.

${ }^{80}$ Stephen I: 14.

${ }^{81}$ Stephen I: 15.

82 Stephen I: 10, 11.

${ }^{83}$ Stephen I: 17.

${ }^{84}$ Stephen I: 33.

85 WenZEL, Codex diplomaticus 7, 1236, Nr. 8.

86 "propter suam multiplicem contumatiam" WENZEL, Codex diplomaticus 1, 1234, Nr. 200 (also in MARSINA, Codex diplomaticus I, under Nr. 426 and 427).

87 "non videatur curare de excommunicatione praedicta" Ebd.

${ }^{88}$ WeNZEL, Codex diplomaticus 12, 1281, Nr. 281.
}

the destruction of church property, unauthorized collection of tithes and other deeds. ${ }^{89}$

\section{Conclusions}

All in all, we confirmed the findings of Western authors that disputes in the Middle Ages did not pursue formal legal patterns as set in laws. Practice was much different from the laws. Thus, the traditional schemes of the system of penalties need to be amended, by adding ecclesiastical penalties and a loss of office, and at the same time relativizing the corporal punishments. The most frequently used were the pecuniary penalties, in the form of compository payment, making no great distinction between judicial and extra-judicial dispute resolution.

Although the daily practice as reconstructed from the Register and the charters thus shows a different world from the one laid down in laws, it is still true that they share the protected interests, i.e. the objects of the disputes.

We assume that prevalence of extrajudicial conflict resolution and the lack of corporal punishment were caused by a special status of the emerging Hungarian nobility with its broad autonomous rights. As the immediate superior authority of this social group was the King whose court was far away, freemen (later nobles) had to settle their disputes among themselves. In the situation of a relatively equal position of an offender and a victim, and of repeated

\footnotetext{
89 "eosdem Magistrum Johannem, Nicolaum Banum et Comitem Henricum ac ipsorum sequaces in festo Annunciacionis Beate Vinginis proxime preterito, in Wereuce, apud ecclesiam Fratrum Minorum, que in honore Beate Virginis Marie est constructa, publice excommunicavimus in scriptis et denunciavimus excommunicatos, pulsatis campanis, candelis accensis et extinctis, et ab omnibus artius evitandos, ac totam terram ipsorum ecclesiastico supponimus interdicto, donec de premissis excessibus et commissis dampnis et iniuriis illatis Deo, Ecclesie et nobis, ac fratribus nostris, Capitulo videlicet Zagrabiensi, satisfaciant" Ebd.
} 
conflicts, corporal punishment was not a solution. Instead, compository payment was imposed with the aim to restore peace and justice.

\section{Korrespondenz:}

Tomáš Gábriš

Comenius University in Bratislava

Faculty of Law

Šafárikovo nám. 6, P.O.Box 313, 81000 Bratislava I,

Slovak Republic

tomas.gabris@flaw.uniba.sk

\section{Literatur:}

János M. BAK, Signs of Conversion in Central European Laws, in: Guyda ARMSTRONG, Ian. N. Wood (Hgg.), Christianizing Peoples and Converting Individuals (Turnhout 2000) 115-124.

János M. BAK, György BÓNIS, James R. SWEENEY (Hgg.), The Laws of the Medieval Kingdom of Hungary, Bd. 1: 1000-1301 (Idyllwild 21999).

Robert BARTLETT, Trial by Fire: The Medieval Judicial Ordeal (Oxford 1999).

Ilona BoLLA, A jogilag egységes jobbágyosztály kialakulása Magyarországon (Budapest 1983).

Warren BROWN, Konfliktaustragung, Schriftlichkeit und persönliche Beziehungen in den karolingischen Formelsammlungen, in: Stefan ESDERS (Hg.), Rechtsverständnis und Konfliktbewältigung (Köln 2007) 31-54.

Geneviève BÜHRER-THIERRY, Just Anger or Vengeful Anger? The Punishment of Blinding in the Early Medieval West, in: Barbara RosenweIN (Hg.), Anger's Past (Ithaca 1998) 75-91.

Nicolas CARRIER, Une Justice pour rétablir la concorde, in: Le Règlement des Conflits au Moyen Âge (Paris 2001) 237-257.

Trevor DeAn, Crime in Medieval Europe (Harlow 2001).

Ferenc ECKHART, Magyar alkotmány és jogtörténet (Budapest 2000).

Guy Geltner, Medieval Prisons: Between Myth and Reality, Hell and Purgatory, in: History Compass 2 (2006) 261-274.

Sarah HAmilton, The Practice of Penance, 900-1050 (Woodbridge 2001).
Zsolt HunYaDI, Signs of Conversion in Early Medieval Charters, in: Guyda ARMSTRONG, Ian. N. Wood (Hgg.), Christianizing Peoples and Converting Individuals (Turnhout 2000) 105-113.

Chronici Hungarici Compositio saeculi XIV, in: Emericus SzENTPÉTERY (Hg.), Scriptores Rerum Hungaricarum, Bd. 1 (Budapest 1937) 217-515.

Joannis KARÁCSONYI, Samuelis BOROVSZKY (Hgg.), Regestrum Varadinense examinum ferri candentis ordine chronologico digestum descripta effigie editionis A. 1550 illustratum sumptibusque capituli Varadinensis Lat. rit. (Budapest 1903).

Jiří KLABOUCH, Staré české soudnictví (jak se dříve soudívalo) (Praha 1967).

John McNeILl, Helena M. GAMER, Medieval Handbook of Penance (New York 1990).

Mary C. MANSFIELD, The Humiliation of Sinners: Public Penance in Thirteenth-Century France (Ithaca 1995).

Richard MARsina (Hg.), Codex diplomaticus et epistolaris Slovaciae, 2 Bde. (Bratislava 19711987).

Richard MARsinA (Hg.), Legendy stredovekého Slovenska (Budmerice 1997).

Barna MEZEY, Der Kerker in der ungarischen Rechtsgeschichte, in: Orsoly Marta PETER, Béla SZABÓ (Hgg.), A bonis bona discere : Festgabe für János Zlinszky zum 70. Geburtstag (Miskolc 1998) 385-420.

Imre SZENTPÉTERY (Hg.), Regesta regum stirpis Arpadianae critico-diplomatica, Bd. I (Budapest 1923).

Imre SZENTPÉTERY, Iván BORSA (Hgg.), Regesta regum stirpis Arpadianae critico-diplomatica, Bd. II/2-3 (Budapest 1961).

Imre SZENTPÉTERY, Iván BORSA (Hgg.), Regesta regum stirpis Arpadianae critico-diplomatica, Bd. II/4 (Budapest 1987).

Adriana ŠveCOVÁ, Tomáš GÁBRIš, Riešenie konfliktov v Uhorsku na podklade stredovekej listinnej praxe 13. a začiatku 14. storočia, in: Právněhistorické studie 40 (2009) 359-377.

Ákos VON TIMON, Ungarische Verfassungs- und Rechtsgeschichte mit Bezug auf die Rechtsentwicklung der westlichen Staaten (Berlin 1904).

Gusztáv Wenzel (Hg.): Codex diplomaticus arpadianus continuatus, 13 Bde. (Pest 1860-1874). 